\title{
Les superlatifs et la définitude en albanais
}

Superlatives and Definiteness in Albanian

\section{Bujar Rushiti and Carmen Dobrovie-Sorin}

\section{(2) OpenEdition}

\section{Journals}

\section{Electronic version}

URL: https://journals.openedition.org/scolia/1854

DOI: 10.4000/scolia.1854

ISSN: 2677-4224

\section{Publisher}

Presses universitaires de Strasbourg

\section{Printed version}

Date of publication: 9 July 2021

Number of pages: 125-140

ISBN: 979-10-344-0091-1

ISSN: 1253-9708

\section{Electronic reference}

Bujar Rushiti and Carmen Dobrovie-Sorin, "Les superlatifs et la définitude en albanais", Scolia [Online], 35 | 2021, Online since 09 July 2021, connection on 13 July 2021. URL: http:// journals.openedition.org/scolia/1854 ; DOI: https://doi.org/10.4000/scolia.1854

Les contenus de la revue Scolia sont mis à disposition selon les termes de la Licence Creative Commons Attribution - Pas d'Utilisation Commerciale - Partage dans les Mêmes Conditions 4.0 International. 
SCOLIA 35/2021, p. 125-140.

\title{
Les superlatifs et la définitude en albanais
}

\author{
Bujar RUSHITI* \\ Université de Paris - LLF \\ Universiteti $A A B$ \\ b.rushiti@outlook.com
}

Carmen DoBrovie-SORIN*

Université de Paris CNRS-LFF

sorin.carmen2@gmail.com

\section{Introduction}

Since Szabolcsi (1986), it has been known that adjectival superlatives are ambiguousbetween an absolute superlative reading and a relative superlative reading:

1) Mary read the longest book.

a. Mary read the longest book out of all the books (in the library).

b. Mary read a book that is longer than all the books read by other students.

According to the absolute superlative reading in (1a), we compare elements of a (contextually restricted) set of books. A DP ${ }^{1}$ that embeds an absolute superlative refers to the member of this set which is at the

* The authors are grateful to LABEX-PLU (10-LABX-0083) for funding the research reported in this paper. We also thank Patricia Cabredo-Hofherr, Karen de Clercq, Ion Giurgea and Lucia Tovena for discussion and comments on various parts of this paper.

1 We follow Abney (1987) and subsequent literature in assuming that an expression such as the book is in fact a DP (determiner phrase) rather an NP (noun phrase). This is known in the literature as the DP-hypothesis. According to this hypothesis, the determiner the in the phrase the book is the head and takes the noun book as its complement. Since the head is occupied by a determiner, the entire projection is a determiner phrase (henceforth, DP). 
top of the scale introduced by the adjective, in this case the scale of length. According to the relative superlative reading in (1b), on the other hand, the comparison crucially involves not only books but also another element in the sentence (called the "correlate"), in this case Mary: the length of the book read by Mary is compared to the lengths of the books read by other people.

Let us stress that the meaning of an absolute superlative is computed DP internally, without taking into account the rest of the sentence. The meaning of the sentence in (1) is obtained by compositionally combining the meaning of the absolute superlative DP with the rest of the clause, which results in conveying that Mary read the entity denoted by the superlative DP, i.e., the book that is the longest out of a contextually restricted set of books, e.g., the books of a given library mentioned or implicit in the context. Relative superlative readings, on the other hand, need to take into account the correlate, which is outside the superlative DP.

The main goal of this paper is to assign a syntactic representation to Albanian superlative DPs by choosing between two structural representations that are known tocorrespond to the superficially identical forms found across Romance language. The main issue will be to decide on whether the definite article sits in the $\mathrm{D}^{\circ}$ position (as in Italian or Spanish, see Loccioni (2018) or instead is part of a superlative DegP constituent (as in Romanian, see Cornilescu and Giurgea (2013), as well as in some of the Frenchsuperlative DPs, see Dobrovie-Sorin (this volume).

\section{Superlative Adjectives in Albanian}

The English sentence in (1) can be uttered in Albanian as in (2) or as in (3), which differ from each other by the position (post- or prenominal) of the adjective:

2) Tomorr-i lexoi libr-in më të trashë. Tomorr.DEF read.PST.3SG book.DEF.ACC CMP AGR thick Tomorr read the longest book. (relative and absolute).

3) Tomorr-i lexoi më të trash-in libër. Tomorr.DEF read.PST.3SG CMP AGR thick.DEF.ACC book.BN Tomorr read the longest book. (absolute only) 
Correlated with the difference in position of the adjective, these examples differ inmeaning: example (2) is ambiguous just like its English counterpart in (1), whereasexample (3) can only have the absolute superlative reading: the comparison can onlyinvolve elements of a given set of books.

Moreover, the examples in (2) and (3) show that (on a par with Romance languagesand unlike Germanic languages) Albanian lacks a dedicated superlative morphology, andinstead expresses superlative meanings by using the comparative form of adjectivesembedded inside a definite DP. In (2) the Albanian DP librin më të trashë "book-the CMP AGR long" does not have any morpheme comparable to the -est in the English the longest book. Librin "book-the" is a noun followed by the definite suffix -in followed by a comparative adjective më të trashë "CMP AGR thick". $M^{\prime}$ is the comparative morpheme, which yields a comparative or superlative reading depending on whether the adjective is unmarked or marked with a definite $\operatorname{article}^{2}$ (cf. $m \ddot{e} t \ddot{e}$ gjatë "CMP AGR long-INDEF" vs më të gjatin "CMP AGR long-the”). Të is an adjectival agreement marker which agrees in case (accusative / ablative) and (in)definiteness with the head noun in both pre-and postnominal position. The form of the agreement marker depends on (in) definiteness of the modified noun, $e$ with adjectives modifying singular definite nouns and $t \ddot{e}$ with adjectives modifying singular indefinite nouns: libr-in e gjatë "book-the AGR long" vs një libër të gjatë "a book AGR long".

The distribution of adjectival agreement markers in Albanian depends on the type ofadjective. Thus, they occur with modifying adjectives but not with classifying adjectives: një libër të gjatë "a book AGR long-INDEF" (meaning "a long book") vs një shkollë elementare "a school elementary" (meaning "an elementary school") ${ }^{3}$.

2 As explained in point 2. below, the definite article on the adjective (in pre-nominal position) or on the noun (when the adjective is post-nominal) is first merged under $\mathrm{D}^{\circ}$ and attaches to either the adjective or the noun, depending on which one is DP-initial.

3 For a more thorough discussion concerning the syntactic distribution of adjectival agreement markers in Albanian such as të, see Trommer (2002) and Alexiadou (2014: 80-90). 
Going back to examples (2) and (3), they reveal two similarities with languages like Italian. The following examples are taken from Coppock \& Strand (2019: 390, ex. (58a) and (58b)).

4) La mammafa $i$ biscotti $\left({ }^{*}\right.$ i) più buoni del mondo. DEF mom makes DEF biscuits ( $\left.{ }^{\star} \mathrm{DEF}\right) \mathrm{CMP}$ tasty of.DEF world My mom makes the yummiest cookies in the world.

5) La mammafa $i$ più buoni biscottidel mondo. DEF mom makes DEF CMP tasty biscuits of.DEF world My mom makes the yummiest cookies in the world.

Example (4) shows that in Italian, the definite article is banned with post-nominal superlatives just as in Albanian. Example (5), on the other hand, is similar to (3) regarding the semantic interpretation: only an absolute superlative reading is conveyed when the superlative adjective is pre-nominal. Examples (2) and (4) provide an interesting contrast with languages like French, where the definite article appears twice, both in the determiner position of the DP (see the le that precedes livre) and in front of the post-nominal superlative adjective (see the le that precedes plus long):

6) Jean a lu le livre le pluslong. John has read DEF book DEF more long John read the longest book.

The Albanian counterpart of this example, given in (7) below, is acceptable only with a comma intonation separating the DP librin "the book" from the post-nominal adjective më të gjatin "the longest", and serves as an answer to questions of the type What happened with Ben?, rather than Who read the longest book?

7) Ben-I ka lexuar libr-in, mëtë gjat-in. Ben.DEF has read book.DEF.ACC, CMP AGR long.DEF.ACC Ben read the book, the longest one.

A good paraphrase of such an example would be "Ben read the book, the longest one", which suggests that the post-nominal definite adjective më të gjatin "CMP AGR long-the" is an elliptical DP, interpreted as "the longest one". It recovers as its antecedent the referent denoted by the DP librin "book-the". Note that an elliptical superlative can show up with indefinite noun phrases as in (8): 
8) Lexova njëlibër, më të gjatin qü kisha në raft. read.1SG a book CMP AGR long.DEF.ACC that had.1SG in bookshelf I read a book, the longest one that I had in my bookshelf.

Quite clearly, the superlative cannot be taken to form a constituent with a noun introduced by an indefinite determiner. The type of examples in (8) thus constitutes evidence in favor of the hypothesis that the definite-marked superlative in (7) is an elliptical superlative DP rather than a post-nominal modifier of the definite-marked noun.

Let us now go back to examples (2) and (3), repeated in (9) below:

9) a. librin më të trashë ("book-the CMP AGR thick")

b. më të trashin libër ("CMP AGR thick-the book")

These DPs can be assumed to rely on the syntactic configurations (10a) and (10b). Thedetails of the syntactic derivation are not directly relevant for the questions raised in thispaper. For concreteness, we assume that pre-nominal superlatives sit in the Spec of a designated functional head $\mathrm{F}^{4}$, where as post-nominal comparatives with superlativemeanings are some kind of reduced relative clause (see Alexiadou (2014), Loccioni(2018)), which for the sake of simplicity we assume sits in an NP-adjunction position.

10) a. Figure 1: N-to-D Raising of the NP hbër "book"

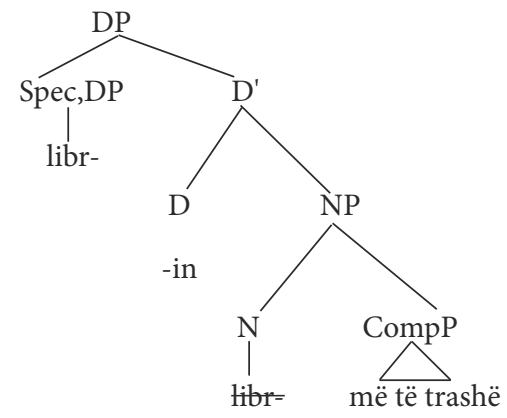

4 For a generalized use of distinct functional heads for each distinct class of adjectives, see Cinque (2010). 
b. Figure 2: Raising of CompP to Spec DP

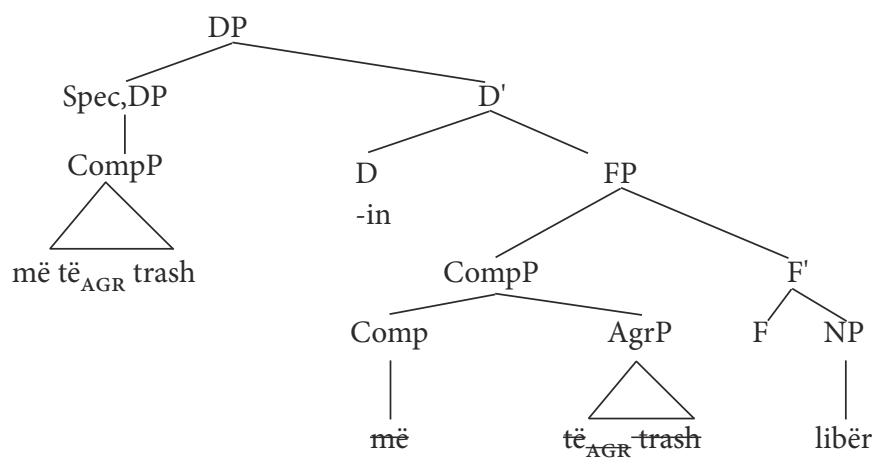

For both (9a) and (9b), represented as in (10a) and (10b), we follow an insight fromDobrovie-Sorin and Giurgea (2006), who argue that adnominal superlatives in languageslike Albanian (also Italian) are formed with a comparative adjective embedded inside adefinite DP. Thus, in both (10a) and (10b), the definite suffix -in is merged in $\mathrm{D}^{\circ}$ and attaches to the right of either the NP or the comparative form depending on which oneraises to Spec DP.

Summarizing, we have argued that in Albanian, superlative meanings of adnominal adjectives are conveyed by using a comparative embedded inside a DP headed by adefinite determiner. This type of configuration (which is essentially the same as that found in Italian) needs to be carefully distinguished from another type of configuration, illustrated above by the French example in (6). As argued by Loccioni (2018) (followingthe references quoted therein), the lower occurrence of the definite article forms aconstituent (labelled SupP) with the comparative, as shown in Figure 3.

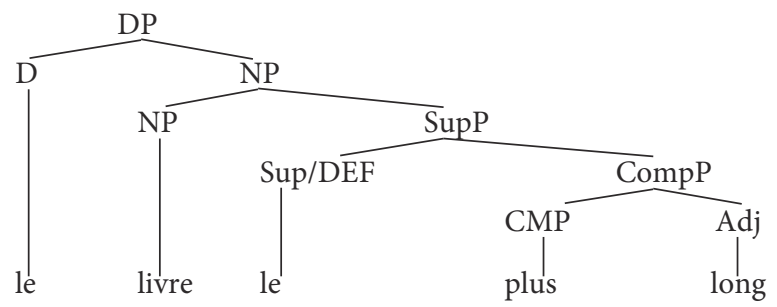

Figure 3: Representation of the superlative DP in (6) 
In sum, Albanian patterns with Italian and contrasts with French in that it lacks adedicated SupP constituent headed by Sup/DEF of the type shown in Figure 3.

\section{When Superlatives Modify the Verb}

Albanian diverges from Italian regarding adverbial superlatives. The Italian example in(11), taken from Loccioni (2018: 184 -ex:(39a)), shows that comparatives with superlative meaning are disallowed, ${ }^{5}$ regardless of the presence or absence of the definite article:

11) Maria scrive $\left({ }^{*}\right.$ il) meglio.

Mary writes $\left({ }^{*} \mathrm{DEF}\right)$ better

Mary writes the best.

In Albanian, on the other hand, the superlative meaning is conveyed by using a DEFsuffix attached to the comparative form of the adverb:

12) Mari-a shkruan më së shpejt-i.

Mary.DEF writes CMP SË fast.DEF

Mary writes the fastest.

Superficially at least, superlatives of this form resemble French superlative adverbs(modulo suffixation, which pertains to $\mathrm{PF}$ ):

13) Marie écrit le plus vite.

Mary writes DEF CMP fast

Mary writes the fastest.

Granting that no DP structure can be assumed inside adverbs, there is no $\mathrm{D}^{\circ}$ in which thedefinite article could be generated. Under this assumption, DEF must be assumed tobelong to the same constituent as the adverb in the comparative degree, yielding asuperlative reading:

5 The only context in which Italian comparative adjectives can be interpreted as superlative is inside relativeclauses (see Loccioni's 2018 examples in 54a). Even in such contexts, the Albanian counterpart requires adefinite marking on the comparative adverb as shown in (i):

(i) Vajz-a që shkruan më së mir-i.

girl.DEF that writes CMP SË good.DEF.

The girl who writes the best. 


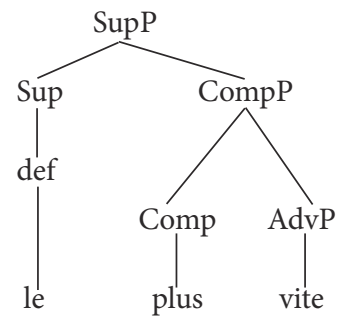

Figure 4: Representation of the superlative adverb in (13)

The structure shown in Figure 4 is not surprising for French, because in this language SupP constituents also exist for postnominal superlative adjectives (see example (6) represented in Figure 3). For Albanian, however, a SupP of the form in Figure 4 would be strictly dependent on the grammatical category: ADVs would require it, whereas ADJs would block it. Although not impossible, this analysis seems suspicious.

In what follows we will propose an alternative that seems more natural to us and whichmoreover has the advantage of explaining the presence of the së-marker, which we haveso far not commented upon. The core idea will be that in Albanian, what we have so farcalled "superlative adverbs" are in fact comparatives embedded inside a definite DPheaded by a null abstract $\mathrm{N}$ with the meaning MANNER (notated [ $\left.\mathrm{N}_{\text {MANNER }} \varnothing\right]$ ):

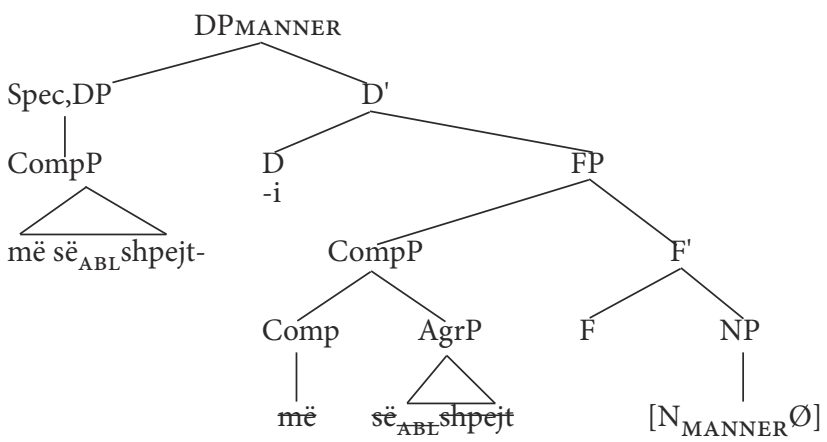

Figure 5: Representation of $\mathrm{V}$-modifying superlatives 
This configuration is identical to the one proposed in Figure (2) for prenominalsuperlative adjectives, modulo two differences: the presence of a null [ $\left.\mathrm{N}_{\text {MANNER }} \varnothing\right]$ instead of the overt N liberr "book" and the presence of $s \ddot{e}$ (which in Albanian grammars isdescribed as the Ablative form of the AGR morpheme) instead of $t \ddot{e}$ (which is the Accusative form of AGR). Under our proposal, the Ablative marking of $s \ddot{e}$ is triggered by agreement with $\left[\mathrm{N}_{\text {MANNER }} \varnothing\right]$. Compare the Accusative marking of $t \ddot{e}$, which appears when the embedding DP is assigned Accusative Case.

Interestingly, $\mathrm{V}$-modifiers in the positive and comparative degree normally lack $s \ddot{e}:^{6}$

14) Mari-a shkruan më (*të) shpejt-i.

Mary.DEF writes CMP ( ${ }^{\star}$ të) fast.DEF

Mary writes the fastest.

Table (1) summarizes the forms of V-modifiers in Albanian:

\begin{tabular}{|c|c|c|}
\hline POS & CMP & SUP \\
\hline Root & më Root & më së Root-DEF \\
\hline shpejt & më shpejt & më së shpejt-i \\
\hline
\end{tabular}

Table 1: V-modifiers

This table shows that the common property of all of the three degree forms of Albanian V-modifiers is the absence of $t \ddot{e}$, which is expected, since $t \ddot{e}$ can only appear on adnominal modifiers. The comparative is formed with $m \ddot{e}$, on a par with adnominal comparatives. Finally, the superlative differs from the comparative by the correlated presence of $s \ddot{e}$ and the definite suffix. Both of these two markers are explained if we assume, as proposedabove, that $\mathrm{V}$-modifying superlatives are Ablative-marked definite DPs built with a $\left[\mathrm{N}_{\text {MANNER }} \varnothing\right]$. Positive and comparative V-modifiers, on the other hand, are "bare" Vmodifiers, in the sense that they lack DP-structure (which may however appear with certain $\mathrm{V}$-modifiers, see footnote 2 ).

In sum, Albanian V-modifying superlatives can be analyzed as comparatives embedded inside a definite DP built with a $\left[\mathrm{N}_{\text {MANNER }} \varnothing\right]$,

6 Së appears with some V-modifiers in the positive forms: së bashku "together", së afërmi "near", së andejmi "from there", së tepërmi "in excess", etc. However, së cannot appear with V-modifiers in the comparative forms: ${ }^{*} m \ddot{e} s \ddot{e}$ afër, ${ }^{*}$ më së tepër. 
the DP itself being marked withAblative Case. No dedicated SupP of the type found in French (and Romanian, notillustrated here) and illustrated in (13)/Figure 4, needs to be assumed. Insofar as it lacksSupP, Albanian resembles Italian. The difference is that Italian does not have Vmodifying DPs made up of comparatives that modify a null $\left[\mathrm{N}_{\text {MANNER }} \varnothing\right]$.

\section{Quantity Superlatives in Albanian}

In this section we will examine the quantity superlatives shumë "many/much" and pak "(a)few/(a)little", which are noteworthy insofar as their prenominal forms have the sameshape as their V-modifying (say "adverbial") forms, whereas their postnominal forms areunremarkable, in the sense that they resemble postnominal quality superlatives. We willtherefore first examine in turn postnominal and V-modifying positions, which confirmthe analyses of quality superlatives proposed in Sections 1 and 2 above. We will then turnto prenominal positions, in which quantity superlatives differ from quality superlativesand instead have the forms characteristic of $\mathrm{V}$-modifiers.

\subsection{Quantity Superlatives in Postnominal Positions}

Let us consider the example below, in which the më të shumtë "CMP AGR many" occurs in the postnominal position of a definite DP:

15) Tomorri kishte lexuar libra-t më të shumtë/paktë. Tomorr.DEF had read books.DEF.ACC CMP AGR many/little Tomorr had read the most/fewest books.

This example shows that the superlative reading of shumë "many/ much" and pak "(a)few/(a)little" is expressed on the same model as postnominal quality superlatives: thesuperlative constituent më të shumtë/paktë carries no definite article, and neverthelessexpresses a superlative reading due to the fact that it is embedded inside a DP headed by a definite article that gets suffixed to the head $\mathrm{N}$ librat "books.DEF.ACC". 
The example in (15) has a relative superlative reading ${ }^{7}$, which says that the set ofbooks Tomorr read contains more books than any other set of books that other relevantindividuals may have read.

\subsection{V-modifying Quantity Superlatives}

Let us now turn to quantity superlatives in V-modifying positions:

16) a. Ben-i punon më së shumt-i.

Ben.DEF works CMP SË much.DEF

Ben works the most.

b. Drit-a foli më së pak-u.

Drita.DEF spoke CMP SË little.DEF

Drita spoke the least.

In (16a) më së shumti "CMP së much-the" indicates that the amount of work Ben does is higher than that of other relevant individuals in the discourse context. (16b) indicates thatamong a relevant set of participants, Drita is the one who spoke the least frequently orless than anybody else. So (16b) conveys a relative superlative reading on the scale offrequency or of duration.

The examples in (16a-b) show that when they function as $\mathrm{V}$-modifiers, quantitysuperlatives are formed on the same model as V-modifying quality superlatives: theAblative form së is used instead of $t \ddot{e}$ and the definite suffix is generated in the $\mathrm{D}_{i}$ positionof a DP built with a null abstract $\mathrm{N}$, which for quantity superlatives can be assumed to be $\left[\mathrm{N}_{\text {QUANTITY }} \varnothing\right]$ (compare [ $\left.\mathrm{N}_{\text {MANNER }} \varnothing\right]$, which we have assumed for quality adjectives in Vmodifying positions).

Table 2 shows the three degree forms of quantity superlatives in V-modifying positions:

\begin{tabular}{|c|c|c|}
\hline POS & CMP & SUP \\
\hline shumë & më shumë & më së shumt-i.DEF \\
\hline pak & më pak & më së pak-u.DEF \\
\hline
\end{tabular}

Table 2: Quantity superlatives in V-modifying positions

7 As is well-known, quantity superlatives do not have absolute readings (see Gawron 1995). Note also thatthe proportional reading of MANY/MUCH is crosslinguistically rare and never allowed in postnominalpositions (Dobrovie-Sorin \& Giurgea 2021). As also pointed out by Dobrovie-Sorin \& Giurgea, Albanianpatterns with Italian in that the proportional reading of MANY/MUCH is only possible in partitiveconfigurations. 
These forms are perfectly parallel to the forms of quality superlatives in V-modifyingpositions (see Table 2). Note indeed that (i) $t^{\prime}$ is absent in all of the three forms (expected, since $t^{\prime}$ is exclusively introduced on adnominal modifiers), (ii) $s$ and the definite suffix are introduced only on the superlative form. The two correlated markings by which the superlative differs from the positive and comparative forms follows naturally from ourhypothesis that V-modifying superlatives are embedded inside Ablative marked definiteDPs built with a null abstract $\left[\mathrm{N}_{\text {QUANTITY }} \varnothing\right]$.

\subsection{Prenominal Quantity Superlatives}

The examples below show that in prenominal positions, quantity superlatives do not takethe form they have in the postnominal position, but rather the form they have when theyfunction as $\mathrm{V}$-modifiers (i.e., $s \ddot{e}$-marking instead of $t \ddot{e}$-marking and presence of the definite suffix), see examples (16)a-b and Table 3:

17) Unëluaj më së shumt-i instrumente.

I play CMP SË many.DEF instruments

I play the most instruments.

18) Ben-i ka më së shumt-i miq.

Ben.DEF has CMP SË many.DEF friends

Ben has the most friends.

In (17), më së shumti "CMP së many.DEF" refers to a cardinality of instruments higher than any other cardinalities of instruments that relevant individuals may play. Thus, of all individuals considered, the speaker plays more instruments than anybody else. ${ }^{8}$ Similarly, (18) says that Ben has more friends than any other relevant individual in thediscourse context.

This interpretation is more or less identical to the one of (15). It would be interesting to explain how a similar meaning arises from two different syntactic configurations, butthis issue will be left for another occasion. Here, we will concentrate on the difference inform ("bare"

8 Example (17) can also take a frequency interpretation. The sentence says that the speaker playsinstruments more frequently than other relevant participants. In such cases, the quantity superlative is to beanalyzed as a V-modifier (on a par with the quantity superlatives in the previous section, see (16a-b) rather than as a prenominal quantity expression. 
comparative form in (15) vs comparative form carrying the definite suffixand preceded by the Ablative-marker $s \ddot{e})$.

The difference in form can be explained if we assume the analysis shown in Figure 6:

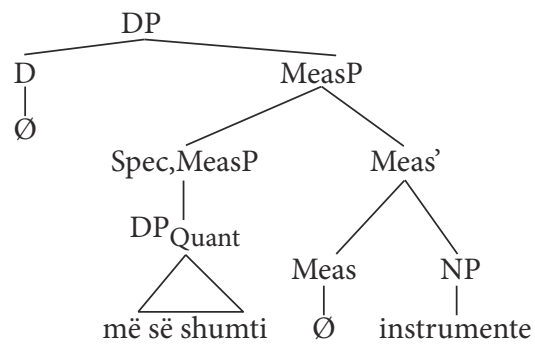

Figure 6: Representation of the superlative DP in (17)

The crucial point is that prenominal quantity superlatives do not sit in the same position as prenominal quality superlatives: the latter occupy a nominal modifier position (intechnical terms, the Spec position of some F head, if we follow Cinque 2010), whereasthe former occupy the Spec position of Meas;, in which Measure Phrases (e.g., $200 \mathrm{~g}$ (of butter)), as well as quantitatives (MANY/MUCH and their degree forms) are assumed to occur (Schwarzschild 2006, Solt 2015). Moreover, what sits in Spec,Meas is not justCompP (as is the case for prenominal quality superlatives) but rather a full DP headed by a null $\mathrm{N}$ [Quant $\varnothing$ ], hence the label $\mathrm{DP}_{\mathrm{Quant}}$, used for readability. Figure 7 shows that the internal structure of $\mathrm{DP}_{\mathrm{Quant}}$ is identical to that of the adverbial superlatives analyzed as $\mathrm{DP}_{\mathrm{Quant}}$. The two configurations differ only by the content of the null N (Quant vs Manner):

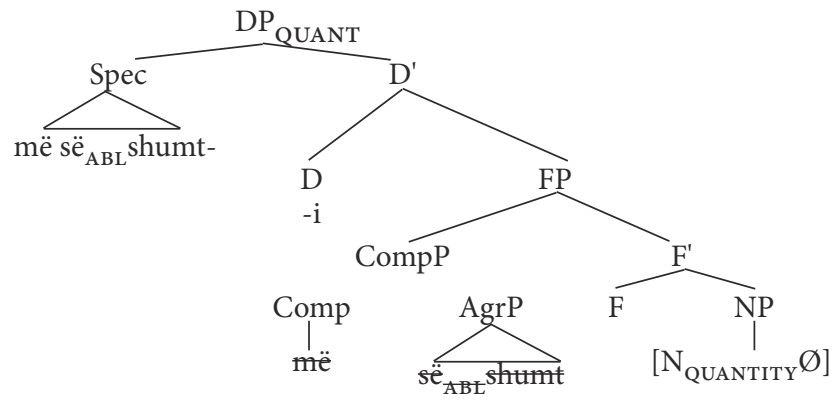

Figure 7: Representation of the quantity superlatives sitting in Spec,Meas 
The presence of $s \ddot{e}$ instead of $t \ddot{e}$ is due to the fact that the AGR relation is established between shumt and [Quant $\varnothing$ ] rather than between shumt and the head $\mathrm{N}$ instrumente (which would trigger të). The definite article does not originate in the $\mathrm{D}_{i}$ that takes theoverall NP as a complement, but rather in the lower $\mathrm{D}_{i}$, the one that takes the NP headed by [Quantity $\varnothing$ ] as a complement. The upper $\mathrm{D}^{\circ}$ is arguably filled with an indefinite-like null $\mathrm{D}^{\circ}$ (see Dobrovie-Sorin, this volume), as indicated in Figure 6.

\section{Conclusion}

We have shown that Albanian is similar to Italian (and Spanish) and differs from French (and Romanian) in that it lacks a dedicated SupP constituent. Superlatives meanings areconveyed by embedding a comparative inside a definite DP.

This generalization is apparently disconfirmed by Albanian adverbial superlatives, which are obligatorily definite-marked. Compare Italian, where (i) the only general wayto convey superlative meaning for comparative adverbs is by adding 'than all the others'and (ii) THE-lacking comparative adverbs can get a superlative reading when appearinginside a relative clause. We have demonstrated that the definiteness marking found onAlbanian superlative adverbs does not constitute evidence in favor of a SupP of the formfound in French or Romanian (see Figure 4). We have instead proposed that Albanian Vmodifying superlatives are comparatives embedded inside a definite DP built with a [ $\left.\mathrm{N}_{\text {MANNER }} \varnothing\right]$, the DP itself being marked with Ablative Case. In so far as it lacks SupP, Albanian resembles Italian. The difference is that Italian does not have V-modifying DPsmade up of comparatives that modify a null [ $\left.\mathrm{N}_{\text {MANNER }} \varnothing\right]$.

We have also shown that quantity superlatives behave on a par with qualitysuperlatives when occurring in postnominal and 'adverbial' positions. In the prenominalposition, on the other hand, quantity superlatives have the form of 'adverbial' superlatives. We have shown that this form can be explained by assuming that prenominal quantity superlatives are definite DPs built with a [N $\left.\mathrm{N}_{\text {Quantity }} \varnothing\right]$, which sit in Spec, Meas.

Our analysis of Albanian superlative V-modifiers can be seen as an illustration ofMatushansky's (2008) claim that the definite marking 
of superlatives signals DP-structure even in those configurations in which we would not expect it, e.g., whensuperlatives are 'adverbial', more precisely V-modifiers. We however do not follow Matushansky in assuming that all definite-marked superlatives involve DP-configurations. Indeed, French and Romanian provide evidence in favor of the presenceof THE inside a dedicated SupP in which no DP level is present (see the French example (13) analyzed as in Figure 4).

\section{References}

ABNEY S. P. (1987), The English noun phrase in its sentential aspect, $\mathrm{PhD}$, Massachusetts Institute of Technology.

ALEXIADOU A. (2014), Multiple determiners and the structure of DPs, Amsterdam/Philadelphia, John Benjamins.

CINQUE G. (2010), The syntax of adjectives: A comparative study, MIT press.

COPPOCK E. \& STRAND L. (2019), Most vs. the most in languages where the more means most, in Aguilar A., Pozas Loyo J. \& Vázquez-Rojas Maldonado V. (eds.), Definiteness across languages, Berlin, Language Science Press, 371-417.

CORNILESCU A. \& GIURGEA I. (2013), The adjective, in DobrovieSorin C. \& Giurgea I. (eds.), A Reference Grammar of Romanian. I: The Noun Phrase, Amsterdam / Philadelphia, John Benjamins, 97-174.

DOBROVIE-SORIN C. (this volume), (In)definiteness in the relative readings of quality and quantity superlatives, Scolia 35, 15-38.

DOBROVIE-SORIN C. \& GIURGEA I. (2006), The suffixation of definite articles in Balkan languages, Revue roumaine de linguistique LI:1, 73-103.

GAWRON, J. M. (1995), Comparatives, superlatives and resolution, Linguistics and Philosophy 18(4), 333-380.

KRASIKOVA S. (2012), Definiteness in superlatives, in Aloni M., Kimmelman V., Roelofsen F., Sassoon G.W., Schulz K. \& Westera M. (eds.), Logic, language and meaning, Heidelberg, Springer, 411-420.

LOCCIONI N. (2018), Getting "the most" out of Romance, Ph.D., University of California, Los Angeles.

MATUSHANSKY, O. (2008), On the attributive nature of superlatives, Syntax 11(1), 26-90. 
SCHWARZSCHILD, R. (2006), The role of dimensions in the syntax of noun phrases, Syntax 9(1), 67-110.

SOLT, S. (2015), Q-adjectives and the semantics of quantity, Journal of semantics 32(2), 221-273.

SZABOLCSI A. (1986), Comparative superlatives, MIT Working Papers in Linguistics 8, 245-265.

TROMMER J. (2002), The post-syntactic morphology of the Albanian pre-posed article: Evidence for Distributed Morphology, Balkanistica 15, 349-364. 